\title{
Assessment of the (Inter) Dependency of Economic Relations between Nigeria and China: 1999-2019
}

\author{
Authors: Femi Omotoso, Goke Kuti, Isaac Olayide O. Oladeji \\ Submitted: \\ Published: \\ 29. February 2020 \\ Volume: \\ 13. March 2020 \\ Issue: \\ Affiliation: \\ Languages: \\ Keywords: \\ Categories: \\ DOI: \\ 7 \\ 2 \\ Ekiti State University, Ado Ekiti, Nigeria \\ English \\ Dependency, Economic Relations, Development, China, Nigeria \\ Humanities, Social Sciences and Law \\ 10.17160/josha.7.2.639
}

Abstract:

This paper examines the economic bilateral diplomatic relationship between Nigeria and China, especially since Nigeria returned to democracy in 1999. The paper argues that while official diplomatic ties were established between the two countries as early as 1970, there was not much bilateral economic, even political, relations between them until recently. However, since 1999, which coincided with the Chinese new orientation towards Africa, there has been an exponential economic relationship between the two countries. The main question this paper grappled with is whether the relationship between the two countries is inter-dependent or not? The paper is wholly qualitative and gathered its data mainly from secondary sources. The paper is based on the dependency theory and the theory of unequal exchange. Findings of the study revealed that, while Nigeria had benefitted immensely from its economic bilateral engagements with China, the relationship is largely imbalance with China being the dominant partner.

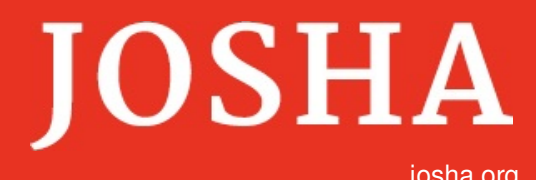

josha.org
Journal of Science, Humanities and Arts

JOSHA is a service that helps scholars, researchers, and students discover, use, and build upon a wide range of content 


\title{
Assessment of the (inter) dependency
}

\section{economic relations between Nigeria and China: 1999-2019}

\author{
By Prof. Femi Omotosoํ, Goke Kuti, Doctoral Candidate ${ }^{2}$ and \\ Dr. Olayide Oladeji ${ }^{3}$
}

${ }^{1}$ Department of Political Science, Ekiti State University Ekiti State, Nigeria.

Femot79@yahoo.co.uk

${ }^{2}$ Department of Political Science, Ekiti State University Ekiti State, Nigeria.

gokekuti@yahoo.com

${ }^{3}$ Department of Political Science, Ekiti State University Ekiti State, Nigeria.

yide.oladeji@gmail.com 


\section{Abstract}

This paper examines the economic bilateral diplomatic relationship between Nigeria and China, especially since Nigeria returned to democracy in 1999. The paper argues that while official diplomatic ties was established between the two countries as early as 1970, there was not much bilateral economic, even political, relations between them until recently. However, since 1999, which coincided with the Chinese new orientation towards Africa, there has been an exponential economic relationship between the two countries. The main question this paper grappled with is whether the relationship between the two countries is interdependent or not? The paper is wholly qualitative and gathered its data mainly from secondary sources. The paper is based on the dependency theory and the theory of unequal exchange. Findings of the study revealed that, while Nigeria had benefitted immensely from its economic bilateral engagements with China, the relationship is largely imbalance with China being the dominant partner. Indeed, Nigeria being a primary community producer and lacking the necessary infrastructure, depend largely on the importation of manufactured goods and infrastructure aid from China to propel local economic development. Thus, the paper concluded that the economic relationship between the two countries is not interdependence but structured by dependency. To reverse the dependency syndrome, the paper makes some policy recommendations on how to drive economic development in Nigeria.

Keywords: Dependency, Economic Relations, Development, China, Nigeria 


\section{Introduction}

Nigeria, during its immediate post-independence period, maintained largely a pro-west foreign policy posture. During this period, Nigeria did not establish any formal diplomatic relationship with China, even when the later sent a delegation to Nigeria in 1964 to seek the establishment of diplomatic ties between the two countries (Bukarambe, 2005). In fact, things got soured between the two countries during the 3 years Nigerian civil war, when the government of China did not only publicly declare support for the secessionist bid of Biafra from the Nigerian state but also was covertly supplying the Biafran administration with arms (Porter, 1986). Things stood like this until February 1971 when the two states established formal diplomatic relations (Mthembu-Salter, 2009; Egbula \& Zheng, 2011).

Despite establishing formal diplomatic ties in 1971, the first thirty years of the NigeriaChina economic relationship was quite slow and, at times, bumpy (Egbula \& Zheng, 2011: 4). For instance, during the military regime of Olusegun Obasanjo, Nigeria complained bitterly about the growing trade imbalance between the two countries. To assuage Nigeria, China agreed to an aid package for Nigeria, which included the sending of medical personnel and agricultural experts to help in the development of new model farms, even though this did nothing to reverse the trade imbalance between the two countries (Ogunsanwo, 2008: 195). During this period, the major bilateral economic relationship between Nigeria and China would take place under the Abacha military government in 1994, when the Nigerian-Chinese Chamber of Commerce was founded (Mthembu-Salter, 2009; Egbula \& Zheng, 2011). Also, the China Civil Engineering Construction Corporation (CCECC) was awarded a $\$ 529$ million ${ }^{4}$ contract to rehabilitate the Nigerian railway system in 1995 (Bukarambe, 2005: 251), while the former premier of China's State Council, Li Ping, visited Nigeria in 1997 to sign protocols relating to power generations, steel, and oil (Utomi, 2008: 40). However, neither the rehabilitation

\footnotetext{
${ }^{4}$ The dollar sign (\$) is used in the paper to mean the US dollar.
} 
of Nigeria's railways nor Li Ping's protocols were implemented before Abacha died in 1998.

Thus, it was not until Nigeria returned to democratic order and the start of China's new orientation towards Africa in the year 2000 that serious economic relations between Nigeria and China started to develop. In fact, while China's economic investment in Africa has grown astronomically over the turn of the century ${ }^{5}$, Nigeria has been one of the major destinations for these investments (Toogood, 2016; Alao, 2011; Egbula \& Zheng, 2011; Mthembu-Salter, 2009). According to Egbula \& Zheng (2011: 3), "there is no bilateral China-Africa relationship evolving faster or impacting more people than the one between China and Nigeria". Incidentally, the new-found love between the two countries coincided with Nigeria's renewed efforts at developing its economy to reduce poverty. ${ }^{6}$ Nigeria's attractiveness to Chinese investments may not be unconnected with its large domestic market of over 200 million inhabitants (www.worldometers.info/worldpopulation/nigeria-population), vast energy reserves and being a regional power in Africa. For Nigeria, the main incentives may lie in China's economic success story and its capacity to deliver and finance large-scale infrastructure projects (Egbula \& Zheng, 2011: 3). However, has the economic relationship between Nigeria and China been mutually beneficial to the two countries? Has Nigerian economic relations with China helped the country in achieving its developmental objectives? If not, what measures

\footnotetext{
${ }^{5}$ The Sino-African trade relationships have grown exponentially after the first Forum on China-Africa Cooperation (FOCAC) in 2000. For instance, China's trade with Africa in 2013 and 2014 exceeded \$200 billion which was more that a ten-fold increase to what it was in the early 2000s. Also, Chinese gross lending to the public sector was estimated at $\$ 132$ billion between 2000-2016, which may account for about $22 \%$ of the total Africa debt within that period (SAIS-CARI, 2018), while its Foreign Direct Investment (FDI), which was about \$390 million in 2005 rose to $\$ 46$ billion in 2018 and is predicted to rise by 13\% in 2019 (Theafricareport Online, 19 September 2019). Indeed, statistics from the General Administration of Customs of China shows that China's volume of import and export with Africa between January and June 2019 was $\$ 102$ billion (MOFCOM, July 27 2019).

${ }^{6}$ In its quest to reduce poverty and show commitment to sustainable growth, the Nigerian government came up with a policy paper in 2004 called the National Economic Empowerment Development Strategy (NEEDS). Also, in 2009 the government made an audacious economic statement to position Nigeria to become one of the 20 strongest economies in the world by the year 2020 through what is called Vision 2020.
} 
could the Nigerian government put in place to ensure that its external economic relations help its developmental drive?

Thus, this paper seeks to grapple with the foregoing and more questions by examining the Nigerian-Chinese economic relations in the Fourth Republic to see whether or not it has been beneficial for Nigeria's quest for economic development and poverty reduction. The rest of the paper is divided into the theoretical analysis, key factors driving the Nigerian-Chinese economic relations, a review of contending issues in China-Africa economic relations; the Nigerian-Chinese, the Nigerian-China economic relations: an interrogation, Concluding remarks: making external economic relations beneficial for Nigeria and Nigerians.

\section{Dependency and Unequal Relationship: A Theoretical Analysis}

This paper shall benefit greatly from the dependency theory and the theory of unequal exchange. Dependency theory was popularised in the 1950s through 1970s and 1980s by a group of radical third world countries scholars (Ake, 1981; Amin, 1957; Dos Santos, 1970; Frank, 1976; Furtado, 1964; Onimode, 1982; Sunkel, 1979), especially in Latin America and Africa, as a way of understanding relations taking place between more advanced and less advanced countries (Ferraro, 1996). Dependency means that a certain group of countries have their economies subjected to or constrained by the development and/or expansion of other economies. Thus, the dependency theory tries to explain the reasons why countries of the south remain poor, while industrialized countries of the north become wealthier. Central to the analysis of dependency theorists is the contention that poor states are impoverished by the way they are integrated into the exploitative world system, especially through colonialism. This development occurred as a global historical phenomenon consequent on the formation, expansion, 
and consolidation of the capitalist system referred to as 'dependent capitalism' (Udeala, 2010: 71). Consequently, the dependency theorists rejected the postulations of the modernization theory and instead argue that the problem of underdevelopment in poor countries is the consequence of the exploitative relationship that characterizes their interactions with the economically advanced countries.

Similarly, the theory of unequal exchange was advanced in the works of some Classically Marxist scholars, especially in Arghiri Emmanuel's (1972) work: Unequal Exchange: A Study of the Imperialism of Trade. The theory explains that the unequal international economic relations and exchange trade between 'developed countries' (DCs) and 'less developed countries' (LCDs) of the world are the main reasons for the exploitation of the latter by the former (Emmanuel, 1972: 10). According to Emmanuel (1972), "unequal exchange (relationship) happens when two unequal countries produce two different commodities so that they are not in direct competition with each other". Emmanuel's theory is based on Karl Marx's theory of 'prices of production' for the determination of international prices and technological changes in production. He argues that the main reason for economic inequality between LCDs and DCs is in the differences in techniques of production and difference in wages, which result in unequal exchange in trade (Udeala, 2010: 73). In should be noted that the argument of the theory of unequal exchange is in agreement with the position of most classical Marxian theorists that the reason for imperialism flows from economic interests as related to the process of capitalist accumulation.

The relevance of these theories to this study lies in the fact that the defining features of an LCD like Nigeria are its dependency on the DCs, which is the result usually of the way the LCDs were integrated into the international capitalism and unequal exchanges between LCDs and DCs being sustained through certain international structures, agencies, and institutions. Since dependency is an integral feature of international capitalism, whenever there is a general crisis it spreads to its peripheries with varying 
degrees of intensity, depending on the extent of control the capitalists have over the peripheral economies (Mac-Ogonor, 1999; Badejo, 1990). While China is still largely regarded as an emerging world economic superpower, its advanced technologicalknowhow does not only give it an advantage in production over Nigeria but also results in unequal/imbalance trade between the two countries. Thus, the theories will enable us to explore how Nigerian leaders entering into economic bilateral relations should consciously and effectively use the country's foreign policy to construct a self-reliant society (Udeala, 2010: 73). Indeed, leadership failure in conducting foreign policy capable of charting an appropriate path for economic development has been blamed as the core reason for Nigeria's continued state of dependence and underdevelopment.

\section{The Nigerian-Chinese Diplomatic Ties in the Fourth Republic}

Nigeria returned to democracy in 1999 after several years of military rule. One of the problems inherited from the military regime by the newly inaugurated civilian administration was a battered economy that did not just plunge the country into debt crisis but also entrapped the masses of the Nigerian population in the pond of abject poverty. Little wonder that the major preoccupation of the Obasanjo led civilian administration was on how to bring the economy out of 'coma' and reduce poverty. To achieve this, Obasanjo's government realized early enough the need to redirect Nigeria's foreign policy, especially to aggressively search for friends ${ }^{7}$. Explaining the reasons for his 'shuttle diplomacy', Obasanjo stated that:

I have devoted much time and energy journeying virtually all corners of the globe in my personal effort to positively reintegrate our country into the international community and attract investment. We are happy to report that the results from these trips have been encouraging enough to confirm my personal belief and the advice of marketing experts

\footnotetext{
${ }^{7}$ In his frantic efforts to reintegrate Nigeria into mainstream global community, between 1999 and August 2002, President Obasanjo made 113 foreign trips and spend 340 days out of the country (Akindele, 2003).
} 
namely that personal contact is the best way to market your product. And my product is Nigeria (Obasanjo, 2002, cited in Oyedoyin, 2002).

Thus, the government did not only connect with countries that have traditionally influenced global affairs and shaped international economic diplomacy but also cultivated deep alliances with emerging global powers that have featured in recent global economic developments (Alao, 2011: 5-6). In fact, over the last two decades, Nigeria has sought to align its foreign policy with domestic developments. Thus, the Nigerian diplomatic relations in the Fourth Republic have involved a cautious balance of devotion to its traditional obligations towards west Africa and African concerns, and the desire to ensure that external relations assist its domestic yearnings for economic development and poverty reduction.

The government's desire to balance the domestic needs and external relations has necessitated a foreign policy that requires extensive outreach diplomacy, especially with an emerging global power like China. Indeed, as noted earlier in this study, the Nigerian-Chinese bilateral relations intensified over the turn of the millennium and has been on the ascendance since then. In fact, the growing bilateral relations between the two countries has earned Nigeria the nickname as 'Africa's China' among international investors (Toogood, 2016: 5). Thus, since 1999, the two countries have signed several diplomatic agreements. These include agreements in trade and investments; on consular matters; cooperation against illicit trafficking; exchange of notes on the provision goods and an agreement on tourism cooperation (Alao, 2011; Bukarambe, 2005; Toogood, 2016; Utomi, 2008; Adunbi \& Stein, 2019). Also, various technical assistance in the military, education, health, and technology have been received by Nigeria.

Consequently, since 2001 there has been increasing bilateral ties between the two countries. In fact, all elected Nigerian presidents in the Fourth Republic have visited 
Beijing, while, at the same time, Chinese presidents, premiers, and top officials have always grabbed any opportunity to stop off in Nigeria anytime they are visiting Africa. However, as noted by Page (2018), despite the growing bilateral ties between the two countries, Nigeria's bilateral relationship with China still lacks the robustness of such relationships of several other African countries with Beijing. For example, compared to Angola, the Republic of Congo, and South Sudan, Nigeria is not a significant supplier of oil to China (Egbula \& Zheng, 2011; Page, 2018). Even Beijing's expansive Belt and Road vision - though there is no single version of it - pass Nigeria by, pivoting to run along Africa's east coast instead. In fact, Nigeria-China relations are not deeply rooted; very few Nigerian elites speak Chinese, have studied in China, or interact regularly with Chinese officials (Page, 2018). That Nigeria is a major importer of Chinese-made goods could be attributed to the effects of globalization and the country's large consumer population.

\section{The Nigerian-Chinese Economic Relations: 1999-2019}

As noted earlier, China's interest in Nigeria reflects its status as an emerging global power as the biggest economy in Africa, a major oil and gas producer, and on track to become the third most populous country in the world by 2050 (Page, 2018: 5). Indeed, Chinese companies have increasingly been investing in Nigeria. For instance, as of 2016, there were 308 registered Chinese companies in Nigeria in various sectors of the Nigerian economy (Adunbi \& Stein, 2019). Also, in a space of five years between 2010 and 2015, Nigeria was the fourth-highest recipient of loans from China in Africa (SAISCARI, 2018). This may have gone up, especially with the $\$ 7.5$ billion loan from China in 2017 to finance the Lagos to Kano and Lagos to Ibadan rails (Adamu, 2017). Between 1995 and 2017, Nigeria has been the second-largest importer of Chinese goods after South Africa. Exports to China have also been in the top five in most years over the same period (UNCTAD, 2018). Although the Nigerian-Chinese economic relationship is multidimensional, this is characterized by trade, oil, and gas, telecommunication, 
agriculture, infrastructure, and security. However, for the purpose of the paper, the Chinese involvements in trade, oil and gas, and security will be discussed, while passing references will be made to its other diplomatic economic ties with Nigeria. These are discussed thematically in what follows.

\section{Nigeria-China Bilateral Trade Relations}

As noted before in this study, over the turn of the millennium, China has become deeply involved in Nigeria. Indeed, by 2009, Nigeria had become one of the leading two-way trade partners of China in Africa and the second-highest African importer from China, after South Africa (Alao, 2011: 16). The trade between Nigeria and China accounts for almost one-third of the trade between China and the entire West African sub-region ${ }^{8}$ (Egbula \& Zheng, 2011: 6). Thus, while the Nigerian-Chinese economic relationship is multidimensional, the most prominent aspect of it has been in the area of trade. In fact, bilateral trade exchanges between the two countries have grown exponentially since 2001 when they first entered into bilateral trade and investment promotion and protection agreement. For example, while the total volume of trade between the two countries in 2000 was $\$ 830$ million (Bukarambe, 2005: 240), it reached a peak in 2014 with a volume of $\$ 18.05$ billion before it declined to $\$ 14.94$ billion and $\$ 10.62$ billion in 2015 and 2016 respectively (Ibrahim \& Sari, 2019: 176). From Table 1 (see Appendix A), it can be seen that primary commodities, especially fuels, dominate Nigeria's exports to China, exceeding 95\% of the total exports in most years (UNCTAD, 2018). On the other hand, over most of the period cover in this study, more than $90 \%$ of Nigeria's total imports from China are finished products, especially consumables and manufactured goods. Also, there has been a persistence of a huge trade imbalance between the two

\footnotetext{
${ }^{8}$ However, despite the growing expansion in trade partnership between the two countries, China accounts for only a fraction of Nigeria's global trade, especially with the United States (top partner), Brazil, India and France (Alao, 2011; Egbula \& Zheng, 2011).
} 
countries in favor of China, which became very high since 2006 and usually in the range of 75 to $92 \%$ of total trade (see Tables $2 \& 3$ ).

Furthermore, a key aspect of the Nigerian-Chinese trade relationship is the preeminent role Nigerian entrepreneurs play in facilitating Chinese imports. Nigeria's major importers of Chinese goods make regular commercial pilgrimages to manufacturing centers in China like Guangzhou (Page, 2018). Also, many Chinese-owned companies are operating in Nigeria across a range of industries, including fabrication, communication and information technology, textile manufacturing, and household consumer goods. These companies are either fully owned by Chinese investors or owned in partnership with Nigerian investors, and usually operating from free-trade zones $^{9}$ (Page, 2018; Adunbi \& Stein, 2019).

However, apart from officially recorded trade between the two countries, there seems to be a great deal of unrecorded trade between them, especially imports from China (Mthembu-Salter, 2009). A great deal of the unrecorded trade between China and Nigeria often travel via neighboring states. Benin is often the most cited country through which Chinese goods are smuggled into Nigeria (Mthembu-Salter, 2009). The unrecorded cross-border trade of Chinese goods ${ }^{10}$ between Benin and Nigeria has become a big-business for thousands of people and present lucrative rent opportunities for corrupt officials on both sides of the border.

\footnotetext{
${ }^{9}$ These free-trade zones are usually purpose-built industrial estates, at times, in partnership with the government of host state. For example, in 2006, the Lagos state government, in partnership with a Chinese Consortium, establish the Lekki Free Trade Zone (LFTZ) (Adunbi \& Stein, 2019).

${ }^{10}$ It must be pointed out that it is not only Chinese goods that are smuggled into Nigeria from her neighbours. In fact, a wide-range of goods - cars, guns, ammunitions, rice, and other consumables - from different countries find their ways into Nigeria through its porous borders with neighbouring countries. This has led the Nigerian government to take a hard-line policy step by closing its land borders against its neighbours.
} 


\section{China's Involvement in Nigeria's Oil and Gas Industry}

While China has a wide range of interests in Nigeria, its major interest is oil (Alao, 2011: 16). China's interest in securing a steady supply of oil and gas for its rapidly growing economy and to avoid overdependence on imports from the Middle East makes the petroleum sector of the Nigerian economy its key investment destination (Egbula \& Zheng, 2011; Page, 2018). The Chinese interest in the Nigerian oil and gas sector became prominent through Obasanjo's 'oil-for-infrastructure' development model, which consisted of awarding oil contracts in exchange for key infrastructural projects ${ }^{11}$ (Bing \& Ceccoli, 2013; Egbula \& Zheng, 2011). Based on this, three major Chinese state-owned companies - China Petroleum \& Chemical Corporation (SINOPEC), China National Petroleum Corporation (CNPC), and China National Offshore Oil Corporation (CNOOC) - were awarded several oil blocks through the right of first refusal (RFR) or auctioning at discounted rates between 2004 and $2007^{12}$ (Egbula \& Zheng, 2011; Wong, 2009; Mthembu-Salter, 2009; Taylor, 2015).

Despite the controversies that surrounded the oil deals under Obasanjo's government, a significant oil-for-infrastructure deal was the concession on four oil blocks awarded to CNPC in exchange for a $\$ 4$ billion investment in infrastructure in 2006 (Hurst, 2006: 11). In fact, there was a dramatic increase in major Chinese investments in the Nigerian oil and gas industry from 2004 (Alao, 2011). Some of these investments will suffice for our purpose here. For instance, in January 2006, CNOOC acquired a $\$ 2.3$ billion majority stake in Akpo oil and gas field (Kelly, 2012; Alao, 2011). Also, the company acquired a $45 \%$ worth $\$ 2.7$ billion stake in offshore deep-water oil fields operated by Total (Alao, 2011). Similarly, SINOPEC has played a significant role in Nigeria's oil industry since its

\footnotetext{
11 Such infrastructures include power generating stations, construction of rail lines, and launching the Nigerian satellite in 2006 (Taylor, 2015; Alao, 2011).

12 It should be noted that most of the oil deals under the Obasanjo's administration, especially at the tail end of it, were marred by controversies and allegations of corruption. In fact, most of the concessions awarded by the administration were revoked by the Ya'Adua's government (Mthembu-Salter, 2009; Gold \& Devadason, 2018).
} 
entry into the industry in 2004. Indeed, in a major oil deal in 2009, believed to be the biggest overseas takeover in Chinese corporate history, SINOPEC purchased Canadian Addax Petroleum for $\$ 7.2$ billion in June 2009 (Mthembu-Salter, 2009: 14). It should be noted that to minimize risks and possibly enhance technological transfer from established industries, Chinese companies prefer to invest in purchasing equity shares in existing oil blocks rather than sole control (Gold \& Devadason, 2018). Consequently, they rely on major international oil companies (IOC) partners in carrying out production, which relieves them of the technological demands that usually come with offshore drilling (Quigley, 2014; Anyu \& Ifedi, 2008).

Indeed, with the stoppage of the oil-for-infrastructure during the Ya'Adua's administration, the Chinese companies willing to invest in Nigeria's market have no choice than competitive bidding processes (Egbula \& Zheng, 2011). Consequently, Chinese companies have been involving in equity acquisitions in either Nigerian companies or other multinational companies operating in Nigeria. In fact, Chinese companies have been largely successful in the bidding processes because of they are fabled to provide infrastructures - rail transport, construction of power stations, dams, roads, and hospitals - mostly below the costs of their Western counterparts (Alao, 2011; Egbula \& Zheng, 2011; Mthembu-Salter, 2009). Indeed, as noted earlier in this study, these developments have led to inflows of Chinese FDI into the Nigerian economy, which stood at $\$ 46$ billion in 2018 and predicted to rise by $13 \%$ in 2019 (Theafricareport Online, 19 September 2019). However, the level of FDI attracted by Nigeria is still low compared to what other recipients of Chinese FDI in Africa, especially South Africa, have been able to attract ${ }^{13}$ (Alabi, Babatunde \& Ogunkola, 2011). Despite this, in an April 2016 official visit to China, President Buhari was able to agree with terms with the Chinese government for the implementation of a Chinese Yuan (CNY) 15 billion Currency Swap Agreement between the Peoples Bank of China and the Central Bank of

${ }^{13}$ It may be difficult to calculate the total amount of Chinese investment in Nigeria. Table 4, however, shows Chinese FDI in Nigeria in comparison to South Africa. 
Nigeria. Also, the Chinese agreed to establish a Transport University in Nigeria ${ }^{14}$, build a Rail Wagon Assembly Plant, and fund the construction of a new deep Sea Port in Warri ${ }^{15}$ (Thinkers Newspaper, December 30, 2019).

\section{Chinese Security Interests in Nigeria}

China has, as a matter of long-standing foreign policy, maintained a non-interference in the internal affairs of other countries. In fact, until recently, China has always seen security challenges in Nigeria as part of the many risks of doing business in the country, unlike the United States and the United Kingdom that see it as their strategic top priority (Page, 2018: 7). Even, when in 2014 the Chinese officials pledged to assist Nigeria in fighting Boko Haram insurgents in the Northeast, it has been difficult to identify any assistance rendered by them since (Boehler, 2014). However, with its investments and nationals coming under consistent great risk of violence in Nigeria, especially in the Niger Delta region, it is not surprising that China has been changing its non-interference policy to acknowledge the need to support the military and peace-building efforts in Nigeria. For instance, the Movement for the Emancipation of the Niger Delta (MEND) claimed that the bomb it detonated a week after Chinese premier's visited Nigeria in 2006 was meant "to warn China's government and its oil companies to steer clear of the Niger Delta.... The Chinese government by investing in stolen crude places its citizens in our line of fire (BBC News, April 30, 2006). Indeed, Chinese citizens, as other nationals, working in the Niger Delta have been targets of kidnappers (Oladeji, 2016).

Consequently, China's investments in military and peace-building-related efforts in Nigeria as in other African countries, such as Angola and Liberia, are closely linked to

\footnotetext{
${ }^{14}$ The project is the baby of the CCECC as part of its corporate social responsibility and it would cost an estimated $\$ 50$ million when it is completed. The construction was flagged off last December in Daura, Katsina State by President Buhari (Construction Review Online, December 9 2019).

${ }^{15}$ Nigeria was also able to secure China's commitment to fund some other high-profile infrastructure projects, namely: the Nigerian railway modernization projects from Lagos to Kano (Lagos-Ibadan, ongoing and nearing completion); and the Mambilla Hydro-electric project (Thinkers Newspaper, December 30, 2019).
} 
its trade and investment interests in the country (Toogood, 2016; Page, 2018). In this context, Beijing's security priorities in Nigeria are likely going to be defensive and reactive - interventionist - placing the physical security of Chinese citizens and their investments first and foremost (Page, 2018: 7). For example, in 2010, China sold 15 F$7 \mathrm{NI}$ fighter aircraft along with air-to-air missiles to Nigeria in a deal estimated to worth \$251 million (Stockholm International Peace Research Institute, 2017). Also, the Chinese state-owned company, Zhong Xing Telecommunication Equipment (ZTE), secured a $\$ 400$ million contract in 2010 to build a national security communications system to be funded by China's Exim Bank (Egbula \& Zheng, 2011: 13). Furthermore, China has supplied combat helicopters and donated two P-18 1,800-ton patrol corvettes to Nigeria for its counterinsurgency operations (Jackson, 2019). In fact, when President Buhari visited China in September 2018 during the Forum on China-Africa Cooperation (FOCAC) meeting, he signed a Memorandum of Understanding (MOU) with Beijing for the supply additional $\$ 1.8$ million worth of counterterrorism equipment (Omonobi, 2019).

However, constrained by Nigeria's rankle sovereignty consciousness, China has been wary of troop deployment in Nigeria. Thus, faced by this constraint, Chinese investors have usually relied on private security guards or off-duty police to safeguard their facilities and personnel (Page, 2018). In some cases, Chinese investors, even though they are not known to be risk-averse, have occasionally had either to operate cautiously or flee potentially dangerous areas. For instance, in 2007, 16 Chinese oil workers were kidnapped in the Niger Delta, while the captain of a Chinese-owned ship was killed in 2012, as were some Chinese construction workers in Borno State, at the heart of the Boko Haram insurgency (Parello-Plesner \& Duchâtel, 2012). Also, a Chinese firm involved in road construction in Kogi State needed to evacuate its expatriate employees from the state after four of them were kidnapped for ransom in early 2018 (Premium Times, April 27, 2018). 


\section{Effects of the Nigerian-Chinese Economic Relations}

The Nigerian-Chinese economic relations, especially in the Fourth Republic, have come with the good, the bad and, at times, the ugly. Indeed, the Chinese economic relations with Nigeria are usually benign but occasionally can be destabilizing (Page, 2018). To be sure, the economic relationship between the two countries in the past two decades has, on the balance, contributed to the socio-economic development of Nigeria. Even though it is often flawed by trade and investment imbalance largely in favor of China, the Chinese investment is quite diversified and does not follow the traditional interest of the West in the country's oil and gas sector only. In fact, China's investment - whether organic or state-directed - generates both formal (such as factory workers) and informal (such as market traders) employment, boosts tax revenues, and creates opportunities for local suppliers (Page, 2018: 8). Nigeria equally benefits economically from bilateral trade with China.

Furthermore, even though Nigeria remains one of the most difficult places to do business in the world, Chinese companies operating in the country depend largely on local labor. A survey of 16 Chinese firms by Chen, et al (2016) shows that each employs an average of 377 Nigerians, which accounts for 85 percent of the total workforce. Also, compared with their Western counterparts, Chinese firms are known to have a higher risk threshold and are open to undertaking work in conflict-prone areas where stability can be enhanced by the employment and infrastructure development that such work generates (Page, 2018). Another key economic benefit Nigeria has gained from its bilateral relations with China is the inflow of aid assistance to Nigeria. For example, over the period 2000-2009, Chinese aid to Nigeria amounted to about $\$ 589$ million (Gold \& Devadason, 2018). Similarly, the Nigerian Investment Promotion Commission (NIPC) reports that Nigeria has received cumulative $\$ 3$ billion from China for investment in economic growth areas like power-sector development, solid minerals, agriculture, rail transportation, and housing infrastructure (This Day, May 8, 2016). 
And herein lies the first noticeable dependency problem in the Nigeria-China economic relationship - the over-reliance of Nigeria on Chinese loans or aids in funding its budget ${ }^{16}$. A country is believed to be suffering from dependency syndrome if it finds it most difficult to complete a budget circle or funds its infrastructural development without relying heavily on borrowings or aids from other countries, especially its trade partners (Ochimi, 2020). Thus and as shown earlier in this paper, Nigeria has largely dependent on aids and investments from China since 1999 either to fund its budget or for infrastructural development in roads, rail systems, power, etc. This again is since China is technologically and economically developed than Nigeria. This has resulted in dependency and unequal exchanges between the two countries with Nigeria being at the receiving end. In fact, a scholar, Professor Adefemi Isumonah, recently remarked that "while Nigerians depend on government for development, the government depends on China for help" (Isumonah, 2020). What Isumonah is saying is that, lately, there has been over-reliance on the Nigerian government on China for its domestic development aspirations.

The second noticeable issue has to with the increased flow of Chinese imports into Nigeria, which has resulted in industrial displacement (Page, 2018; Jackson, 2019). The surge of foreign textile imports from China, for instance, has led to the near disappearance of Nigeria's domestic textile industry (Jackson, 2019). Indeed, given Nigerians high taste for foreign goods, government importation ban on textiles and other domestically made goods has done little to stem the situation, rather it has fuelled smuggling. Little wonder, Nigerian business leaders have complained as early as 2005 that the Nigerian textile industry had closed 65 mills while about 180, 000 workers lost their jobs as of 2010 (Sodhi, 2010; Taylor, 2008). But, Nigerian cloth traders tend to be happy with the situation because they make more money from the sale of the imported

\footnotetext{
${ }^{16}$ It should be noted that Nigeria does not rely on China alone for its borrowings. Nigeria borrows and relies on aids from other countries and international development organizations like the US, UK, Germany, France, the EU, World Bank, IMF, etc.
} 
Chinese clothes (Renee, 2015). It must, however, be stated that the dominance of the Chinese textiles in the Nigerian markets has a lot to do with the declining industrialization in Nigeria right from the 1980 and upsurge in manufacturing technology in China. In fact, many Nigerian manufacturers rely on the Chinese manufacturing industries for the production of their brands. That is, due to the lack of modern technology and near collapse of infrastructures, it becomes cheaper for textile manufacturers in Nigeria to produce in China (Adunbi \& Stein, 2019; Renee, 2015).

The third issue has been the persistent trade imbalance between the two countries. Experience has actually shown that bilateral relations between two unequal partners will invariably end up to the overall disadvantage of the weaker party, and in the case between Nigeria and China, Nigeria (Udeala, 2010: 75). The persistence of this pattern of lopsided economic relationship has serious implications for Nigeria. For instance, it results in the intensification of dependent relationships, which provide an enormous advantage to China in the continuation of its economic and industrial expansion. The third issue has to do with Chinese companies' labor practices. There has been a complaint about the conditions in Chinese-owned factories, which have been criticized for being 'closed' due to perceived low levels of employing local experts (Jackson, 2019: 58). In fact, labor unions complain that Nigerian workers are poorly paid and rarely rise to management level in Chinese companies (Page, 2018). Some reports equally accuse Chinese firms of neither obeying Nigerian Labour Laws nor that of the International Labour Organization (Egbula \& Zheng, 2011). This was highlighted when several Nigerian workers died after being trapped inside a locked Chinese-owned factory that caught fire in 2002 (Jonker \& Robinson, 2018: 109).

Another major issue in the Nigeria-China economic relation has to do with the shoddy Chinese goods being imported to Nigeria. This issue was so serious that it was one of the issues raised in a bilateral talk in Beijing. According to the Director-General of the Standards Organization of Nigeria, John Akanya, "it is worrisome to see sub-standard 
industrial goods being imported to Nigeria from China given the common knowledge that very high-quality goods are being exported from China to other parts of the world..." (Akanya, 2010, cited in Nwosu, 2011). However, the flow of defective imports may not be blamed on a Chinese government conspiracy, as most people would want to think, instead, they are driven by opportunistic Nigerian traders. For instance, while China acknowledges the problem of shoddy goods, it says that Nigerian importers often pressure Chinese suppliers to produce lower quality products in order to reduce the prices to level Nigerians can afford (Egbula \& Zheng, 2011).

Furthermore, a critical issue in the bilateral relations between China and Nigeria is the disadvantaged position of Nigerian merchants trading with China relative to their international counterparts (Page, 2018). For example, Nigerian traders' commercial activities are constrained by high travel costs, restrictive Chinese visa policies, and an antiquated air-service agreement that allows only one airline from each country to fly into one city in the other country, such as Lagos and Guangzhou (Ibid). Lastly, at issue is the intellectual property rights between Nigerian manufacturers and their Chinese partners. For example, Nigerian textile traders often send their designs via smartphone camera to prospective manufacturing partners in China to solicit bids, only to find these unique designs show up elsewhere without approval (Renee, 2015: 220-22). This is noted in some of the Nigerian partners of Chinese companies in the FTZs and a variety of other manufacturing ventures (Jackson, 2019).

\section{Conclusion and Policy Recommendations}

The paper investigated the economic relationship between Nigeria and China in the Fourth Republic. The paper noted that why there were slow diplomatic ties between the two countries in the early post-independence period of Nigeria, this has accelerated since Nigeria returned to democracy two decades ago. While Nigeria could be said to have gained immensely from its bilateral economic relations with China, the paper 
observed that the relationship between the two countries is still one between two unequal partners. That is, China remains the dominant partner while Nigeria has always maintained a dependent position. For example, while China has a robust foreign policy agenda towards Nigeria nay Africa, it is still difficult to pinpoint a coherent Nigerian foreign policy towards China.

Also, while China is undoubtedly a global economic power with a strong technological base and capacity to fund its budget without recourse to aid or borrowings, the same may not be said of Nigeria that has largely been an exporter of primary commodities and usually fund its budget mostly through aids and borrowings. In fact, China, over the turn of the millennium, has become a major donor and lender to Nigeria. But, what can Nigeria do to benefit more from its international economic relations? In view of this, the following policy recommendations are made:

1. Nigeria has to come up with a robust economic policy that reflects its national interest and that will guide its bilateral or multilateral international economic relations. Such a policy must protect Nigeria against the domination of foreign enterprises.

2. To improve the international trade balance, Nigeria needs to diversify its economy and invest in the productive sectors to become an exporter of finished goods and gain economically from the export of such made-in-Nigeria goods.

3. Nigeria needs to learn particularly from Chinese socio-economic development. That is to bring to reality Nigeria's quest for industrialization, it may not be out of place for Nigeria to borrow the Chinese model.

4. Lastly, it is time for Nigeria, as a leader in Africa, to lead a strategy for SouthSouth investment cooperation, especially capable ensuring effective productive linkage among the private sector of member countries. 


\section{APPENDIX A}

Table 1: Nigeria-China Exports 1995-2017 in \$ Millions except Ratios

\begin{tabular}{|l|l|l|l|l|l|}
\hline Year & $\begin{array}{l}\text { Exp. } \\
\text { Manuf. }\end{array}$ & Man./Tot & $\begin{array}{l}\text { Exp. } \\
\text { Fuels }\end{array}$ & Fuels/Tot & $\begin{array}{l}\text { Tot } \\
\text { Exports }\end{array}$ \\
\hline 1995 & .3 & 0.005455 & 53 & 0.963636 & 55 \\
\hline 2000 & .07 & 0.000348 & 177 & 0.880597 & 201 \\
\hline 2005 & 16 & 0.030361 & 491 & 0.931689 & 527 \\
\hline 2006 & 11 & 0.034483 & 285 & 0.893417 & 319 \\
\hline 2007 & 39 & 0.058824 & 603 & 0.909502 & 663 \\
\hline 2008 & 52 & 0.095941 & 433 & 0.798893 & 542 \\
\hline 2009 & 63 & 0.059943 & 932 & 0.886775 & 1051 \\
\hline 2010 & 239 & 0.180106 & 958 & 0.721929 & 1327 \\
\hline 2011 & 270 & 0.12987 & 1497 & 0.720058 & 2079 \\
\hline 2012 & 62 & 0.032074 & 1599 & 0.827212 & 1933 \\
\hline 2013 & 62 & 0.032856 & 1623 & 0.860095 & 1887 \\
\hline 2014 & 48 & 0.014674 & 2703 & 0.826353 & 3271 \\
\hline 2015 & 52 & 0.037901 & 959 & 0.69898 & 1372 \\
\hline 2016 & 31 & 0.034368 & 588 & 0.651885 & 902 \\
\hline 2017 & 87 & 0.049014 & 1300 & 0.732394 & 1775 \\
\hline
\end{tabular}

Source: UNCTAD, 2018

Table 2. Nigerian Foreign Trade, 2000-2018 (USD million)

\begin{tabular}{|c|c|c|c|c|c|c|}
\hline Year & $\begin{array}{c}\text { Imports } \\
\text { from world }\end{array}$ & $\begin{array}{c}\text { Exports } \\
\text { to } \\
\text { world }\end{array}$ & $\begin{array}{c}\text { Imports } \\
\text { from } \\
\text { China }\end{array}$ & $\begin{array}{c}\text { Imports } \\
\text { from } \\
\text { China } \\
\text { as \% } \\
\text { world }\end{array}$ & $\begin{array}{c}\text { Exports } \\
\text { to } \\
\text { China }\end{array}$ & $\begin{array}{c}\text { Exports } \\
\text { to } \\
\text { China } \\
\text { as } \% \\
\text { world }\end{array}$ \\
\hline 2000 & $\$ 22,764$ & $\$ 8,183$ & $\$ 253$ & $1.11 \%$ & $\$ 140$ & $1.71 \%$ \\
\hline 2001 & $\$ 20,854$ & $\$ 10,804$ & $\$ 527$ & $2.53 \%$ & $\$ 127$ & $1.18 \%$ \\
\hline 2002 & $\$ 17,256$ & $\$ 12,019$ & $\$ 739$ & $4.28 \%$ & $\$ 73$ & $0.61 \%$ \\
\hline 2003 & $\$ 25,327$ & $\$ 13,836$ & $\$ 1,067$ & $4.21 \%$ & $\$ 123$ & $0.89 \%$ \\
\hline 2004 & $\$ 35,507$ & $\$ 15,915$ & $\$ 1,015$ & $2.86 \%$ & $\$ 797$ & $5.01 \%$ \\
\hline 2005 & $\$ 47,590$ & $\$ 19,015$ & $\$ 1,398$ & $2.94 \%$ & $\$ 908$ & $4.77 \%$ \\
\hline 2006 & $\$ 62,346$ & $\$ 22,143$ & $\$ 1,755$ & $2.81 \%$ & $\$ 478$ & $2.16 \%$ \\
\hline 2007 & $\$ 71,244$ & $\$ 29,711$ & $\$ 2,349$ & $3.30 \%$ & $\$ 926$ & $3.12 \%$ \\
\hline 2008 & $\$ 91,946$ & $\$ 42,758$ & $\$ 4,190$ & $4.56 \%$ & $\$ 878$ & $2.05 \%$ \\
\hline 2009 & $\$ 55,088$ & $\$ 32,964$ & $\$ 3,400$ & $6.17 \%$ & $\$ 1,547$ & $4.69 \%$ \\
\hline 2010 & $\$ 82,479$ & $\$ 36,895$ & $\$ 4,159$ & $5.04 \%$ & $\$ 1,840$ & $4.99 \%$ \\
\hline
\end{tabular}




\begin{tabular}{|l|c|c|c|c|c|c|}
2011 & $\$ 114,316$ & $\$ 49,184$ & $\$ 5,717$ & $5.00 \%$ & $\$ 2,722$ & $5.53 \%$ \\
\hline 2012 & $\$ 113,326$ & $\$ 44,366$ & $\$ 5,785$ & $5.10 \%$ & $\$ 2,181$ & $4.92 \%$ \\
\hline 2013 & $\$ 101,795$ & $\$ 49,746$ & $\$ 7,487$ & $7.35 \%$ & $\$ 2,658$ & $5.34 \%$ \\
\hline 2014 & $\$ 98,994$ & $\$ 53,314$ & $\$ 9,603$ & $9.70 \%$ & $\$ 4,573$ & $8.58 \%$ \\
\hline 2015 & $\$ 55,342$ & $\$ 41,401$ & $\$ 8,483$ & $15.33 \%$ & $\$ 2,131$ & $5.15 \%$ \\
\hline 2016 & $\$ 37,831$ & $\$ 32,066$ & $\$ 6,418$ & $16.97 \%$ & $\$ 1,550$ & $4.83 \%$ \\
\hline 2017 & $\$ 47,788$ & $\$ 37,877$ & $\$ 7,623$ & $15.95 \%$ & $\$ 2,782$ & $7.35 \%$ \\
\hline 2018 & $\$ 64,188$ & $\$ 43,630$ & $\$ 8,507$ & $13.25 \%$ & $\$ 3,219$ & $7.38 \%$ \\
\hline
\end{tabular}

Source: IMF DOTS, 2019

Table 3. Chinese foreign trade, 2000-2018 (USD million)

\begin{tabular}{|c|c|c|c|c|c|c|}
\hline Year & $\begin{array}{c}\text { Imports } \\
\text { from world }\end{array}$ & $\begin{array}{c}\text { Exports to } \\
\text { world }\end{array}$ & $\begin{array}{c}\text { Imports } \\
\text { from } \\
\text { Nigeria }\end{array}$ & $\begin{array}{c}\text { Nigeria } \\
\text { Imports } \\
\text { as } \% \\
\text { world }\end{array}$ & $\begin{array}{c}\text { Exports } \\
\text { to } \\
\text { Nigeria }\end{array}$ & $\begin{array}{c}\text { Nigeria } \\
\text { Exports } \\
\text { as } \% \text { world }\end{array}$ \\
\hline 2000 & $\$ 404,119$ & $\$ 221,325$ & $\$ 293$ & $0.07 \%$ & $\$ 564$ & $0.25 \%$ \\
\hline 2001 & $\$ 417,209$ & $\$ 227,797$ & $\$ 227$ & $0.05 \%$ & $\$ 919$ & $0.40 \%$ \\
\hline 2002 & $\$ 486,789$ & $\$ 278,246$ & $\$ 134$ & $0.03 \%$ & $\$ 1,047$ & $0.38 \%$ \\
\hline 2003 & $\$ 611,931$ & $\$ 386,197$ & $\$ 72$ & $0.01 \%$ & $\$ 1,787$ & $0.46 \%$ \\
\hline 2004 & $\$ 799,118$ & $\$ 504,667$ & $\$ 463$ & $0.06 \%$ & $\$ 1,719$ & $0.34 \%$ \\
\hline 2005 & $\$ 987,714$ & $\$ 603,624$ & $\$ 527$ & $0.05 \%$ & $\$ 2,305$ & $0.38 \%$ \\
\hline 2006 & $\$ 1,195,410$ & $\$ 723,400$ & $\$ 278$ & $0.02 \%$ & $\$ 2,856$ & $0.39 \%$ \\
\hline 2007 & $\$ 1,455,306$ & $\$ 859,452$ & $\$ 537$ & $0.04 \%$ & $\$ 3,800$ & $0.44 \%$ \\
\hline 2008 & $\$ 1,674,596$ & $\$ 1,009,718$ & $\$ 510$ & $0.03 \%$ & $\$ 6,758$ & $0.67 \%$ \\
\hline 2009 & $\$ 1,421,496$ & $\$ 914,776$ & $\$ 898$ & $0.06 \%$ & $\$ 5,478$ & $0.60 \%$ \\
\hline 2010 & $\$ 1,810,129$ & $\$ 1,249,978$ & $\$ 1,068$ & $0.06 \%$ & $\$ 6,695$ & $0.54 \%$ \\
\hline 2011 & $\$ 2,062,702$ & $\$ 1,528,895$ & $\$ 1,580$ & $0.08 \%$ & $\$ 9,201$ & $0.60 \%$ \\
\hline 2012 & $\$ 2,152,993$ & $\$ 1,559,409$ & $\$ 1,266$ & $0.06 \%$ & $\$ 9,308$ & $0.60 \%$ \\
\hline 2013 & $\$ 2,236,576$ & $\$ 1,651,145$ & $\$ 1,543$ & $0.07 \%$ & $\$ 12,045$ & $0.73 \%$ \\
\hline 2014 & $\$ 2,373,208$ & $\$ 1,647,823$ & $\$ 2,655$ & $0.11 \%$ & $\$ 15,449$ & $0.94 \%$ \\
\hline 2015 & $\$ 2,312,298$ & $\$ 1,442,952$ & $\$ 1,237$ & $0.05 \%$ & $\$ 13,648$ & $0.95 \%$ \\
\hline 2016 & $\$ 2,246,791$ & $\$ 1,383,678$ & $\$ 900$ & $0.04 \%$ & $\$ 10,326$ & $0.75 \%$ \\
\hline 2017 & $\$ 2,436,584$ & $\$ 1,663,024$ & $\$ 1,615$ & $0.07 \%$ & $\$ 12,264$ & $0.74 \%$ \\
\hline 2018 & $\$ 2,630,278$ & $\$ 1,877,436$ & $\$ 1,869$ & $0.07 \%$ & $\$ 13,687$ & $0.73 \%$ \\
\hline
\end{tabular}


Source: IMF DOTS, 2019.

Table 4. China: FDI Stocks in Nigeria and South Africa, 2003-2017

\begin{tabular}{|c|c|c|}
\hline Year & $\begin{array}{c}\text { Total Stock: Nigeria (USD } \\
\text { million) }\end{array}$ & $\begin{array}{c}\text { Total Stock: South Africa } \\
\text { (USD million) }\end{array}$ \\
\hline 2003 & $\$ 32$ & $\$ 44.77$ \\
\hline 2004 & $\$ 76$ & $\$ 58.87$ \\
\hline 2005 & $\$ 94$ & $\$ 112.28$ \\
\hline 2006 & $\$ 216$ & $\$ 167.62$ \\
\hline 2007 & $\$ 630$ & $\$ 702.37$ \\
\hline 2008 & $\$ 796$ & $\$ 3,048.62$ \\
\hline 2009 & $\$ 1,026$ & $\$ 2,306.86$ \\
\hline 2010 & $\$ 1,211$ & $\$ 4,152.98$ \\
\hline 2011 & $\$ 1,416$ & $\$ 4,059.73$ \\
\hline 2012 & $\$ 1,950$ & $\$ 4,775.07$ \\
\hline 2013 & $\$ 2,146$ & $\$ 4,400.40$ \\
\hline 2014 & $\$ 2,323$ & $\$ 5,954.02$ \\
\hline 2015 & $\$ 2,377$ & $\$ 4,722.97$ \\
\hline 2016 & $\$ 2,542$ & $\$ 6,500.84$ \\
\hline 2017 & $\$ 2,862$ & $\$ 7,472.77$ \\
\hline
\end{tabular}

Source: SAIS-CARI 2019. 


\section{References}

Adamu, A. (2017). Nigeria secures $\$ 7.5$ billion loan from China for rail project Amaechi. Premium Times, Feb. https://www.premiumtimesng.com/news/headlines/222767-updatenigeria-secures-7-5billion-loan-china-rail-project-amaechi.html, accessed December 12, 2019.

Ademuyiwa, I., Onyekwena, C., Taiwo, O. and Uneze, E. (2014). Nigeria and the BRICS: Current and Potential Trade Relations and Their Implications for the Nigerian Economy, Occasional Paper no. 184. Johannesburg: South African Institute of International Affairs.

Adunbi, O. and Stein, H. (2019). The Political Economy of China's Investment in Nigeria: Prometheus or Leviathan? In Justin Lin and Arkebe Oqubay (eds.), ChinaAfrica and an Economic Transformation, Oxford: Oxford University Press.

Ake, C. A. (1981). Political Economy of Africa, London: Longman Group Ltd.

Akindele, R.A. (2003). Foreign Policy in Federal Politics. A Case Study Nigeria. Lagos: World Press.

Alabi, O.G., Babatunde, M.A. and Ogunkola, E.O. (2011). An analysis of China-Nigeria Investment Relations. Journal of Chinese Economic and Foreign Trade Studies, Vol. 4, pp. 183-199.

Alao, A. (2011). Nigeria and the Global Powers: Continuity and Change in Policy and Perceptions. Occasional Paper No. 96. South African Institute of International Affairs.

Amin, S. (1972). Unequal Development, New York: Monthly Review Press.

Anyu, J.N. and Ifedi, J.P.A. (2008). China's ventures in Africa: Patterns, prospects, and implications for Africa's development. Mediterranean Quarterly, Vol. 19, pp. 91-110.

Badejo, B, (1990). Nigeria's Economic Relationship with Brazil and India: An Assessment of South-South Cooperation, Nigerian Journal of International Affairs, Vol. 16(1).

BBC News (2006). Car blast near Nigeria oil port, April 30, http://news.bbc.co.uk/2/hi/africa/4959210.stm, accessed September 28, 2019.

Bing, J.H. and Ceccoli, S.J. (2013). Contending narratives in China's African development. Journal of Third World Studies, Vol. 30, pp. 107-136. 
Boehler, P. (2014). China pledges help to Nigeria's hunt for Boko Haram militants, South China Morning Post, May 8, www.scmp.com/news/chinainsider/article/1507498/china-pledges-help-nigerias-hunt-boko-haram-militants, accessed November 22, 2019.

Bukarambe, B. (2005). Nigeria-China Relations: The unacknowledged Sino-dynamics, in Ogwu, J, (ed.), New Horizons for Nigeria in World Affairs. Lagos: Nigerian Institute of International Affairs.

Chen, Y., Irene, Y.S., Rex, U., et al. (2016). Learning from China? Manufacturing, Investment, and Technology Transfer in Nigeria. Washington, DC: Johns Hopkins University School of Advanced International Studies, China-Africa Research Initiative.

Construction Review Online (2019). Construction of Transport University in Nigeria Begins, December 9, http://constructionreviewonline.com/2019/12/construction-oftransport-university-in-nigeria-begins, accessed January 7, 2020.

Don Santos, T, (1968). El - Nuevo caracter de la dependecia. (Guadero No.10) Santiago.

Egbula, M. and Zheng, Q. (2011). China and Nigeria: A Powerful South-South Alliance, West African Challenges, No.5, Sahel and West Africa Club Secretariat.

Emmanuel, A. (1972). Unequal Exchange: A Study of the Imperialism of Trade, New York: Monthly Review Press.

Ferraro, V. (1996). Dependency Theory: An Introduction. Paper presented at Mount Holyoke College, South Hadley, M.A. July 1996, http://www.mtholyoke.edu/acad/intrel/depend.htm, accessed September 20, 2019.

Frank, A. G. (1979). Dependent Accumulation and Underdevelopment in Latin America, New York: Monthly Review Press.

Furtado, C. (1965). Development and Stagnation in Latin America, Studies in International Development, Vol. I (11).

Gold, K.L. and Devadason, E.S. (2018). The Engagement of China in Nigeria's Oil Sector: Is the Transformation Positive? Contemporary Chinese Political Economy and Strategic Relations: An International Journal, Vol. 4(3), pp. 1025-1060.

Hurst, C. (2006). China's Oil Rush in Africa. Energy Security. Washington, DC: Institute for the Analysis of Global Security. 
Ibrahim, K.H. and Sari, D.W. (2019). Nigeria-China: An Examination of Recent Bilateral Trade Relations. International Journal of Applied Research in Social Sciences, Vol. 1(5), pp. 172-184.

Ikhuoria, E. (2010). The Impact of Chinese Imports on Nigeria Traders, in Axel HarneitSievers, Stephen Marks, and Sanusha Naidu (eds.), Chinese and African Perspectives on China in Africa, Cape Town, South Africa: Paambazuka Press.

Isumonah, V.A. (2020). Chance or Planned Development: Interrogating Nigeria's Developmental Process. Paper Delivered at the Preretirement Luncheon and Lecture in Honour of Professor Dipo Kolawole, Organized by Obafemi Awolowo University, Ile-Ife, Nigeria held on Tuesday, January 28, 2020.

Jackson, S. F. (2019). Two Distant Giants China and Nigeria Perceive Each Other, European, Middle Eastern, \& African Affairs, Winter, pp. 40-74.

Jonker, K. and Robinson, B. (2018). China's Impact on the African Renaissance: the Baobab Grows. Singapore: Palgrave Macmillan.

Kelley, J. (2012). China in Africa: Curing the resource curse with infrastructure and modernisation. Sustainable Development Law \& Policy, Vol. 12, pp.35-60.

Mac-Ogonor, C. U. (1999). South-South Cooperation and Nigeria-South Korea Relations: A Case of Unequal Economic Relations, in Okedudu, Stephen (ed.), Selected Issues in Third World Development Crisis: Evidence from Nigeria, Port-Harcourt: Paragraphics.

Mthembu-Salter, G. (2009). Elephants, Ants and Superpowers: Nigeria's Relations with China, Occasional Paper, 42. Johannesburg: South African Institute of International Affairs.

Nwosu, N. (2011). Country to Overtake South Africa as China's Trading Partner? This Day, 14 September, https://allafrica.com/stories/201109141061.html, accessed November 20, 2019.

Ochimi, G. (2020). Personal Interview with Dr. Godwin Ochimi, January 18.

Ogunsanwo, A. (2008). A Tale of Two Giants: Nigeria and China, in Ampiah K. \& S. Naidu (eds.), Crouching Tiger, Hidden Dragon? Scottsville: University of KwaZulu-Natal Press. 
Oladeji, I.O. (2016). Security of Life and Property: Armed Robbery and Kidnapping in Nigeria. In Femi Omotoso \& Michael Kehinde (eds.), Democratic Governance and Political Participation in Nigeria: 1999-2014, Denver: Spear Media Press. pp. 359-380.

Omonobi, K. (2019). Counterinsurgency: Nigeria, China Sign MOU on Military Cooperation. Vanguard News Online, 11 June. https://www.vanguardngr.com/2019/01/counter-insurgency-nigeria-china-sign-mou-onmilitary-cooperation/, accessed 22 December, 2019.

Onimode, B. (1982).Imperialism and Underdevelopment in Nigeria, London: Zed Press.

Oyedoyin, T. (2002). Obasanjo woos foreign investors to Nigeria, Nigeriaworld News, 18 July, nigeriaworld.com/feature/publication/oyedoyin/0718-202.html, accessed November 20, 2019.

Page, M.T. (2018). The Intersection of China's Commercial Interests and Nigeria's Conflict Landscape. Washington, DC: United States Institute of Peace.

Parello-Plesner, J. and Duchâtel, M. (2015). China's Strong Arm: Protecting Citizens and Assets Abroad. London: International Institute for Strategic Studies.

Porter, B. (1986). The USSR in Third World Conflict. Cambridge: Cambridge University Press.

Premium Times (2018). Chinese expatriates flee Lokoja-Okene road project - Manager, April 27, www.premiumtimesng.com/news/more-news/266453-insecurity-chineseexpatriates-flee-lokoja-okene-road-project-manager.html, accessed January 5, 2020.

Quigley, S. (2014). Chinese oil acquisitions in Nigeria and Angola. Department of Political Science, The American University in Cairo http://schools. aucegypt.edu/huss/pols/khamasin/Pages/article. aspx?eid=14.

Renee, E. P. (2015). The Changing Context of Chinese-Nigerian Textile Production and Trade, 1900-2015, Textile, Vol. 13(3).

SAIS-CARI (2018). Data. http://www.sais-cari.org/data/, accessed December 12, 2019.

Sodhi, N.S. (2010). Textiles and Beyond. Presentation to the AGOA Civil Society Forum, Woodrow Wilson International Center for Scholars, www.wilsoncenter.org/sites/default/files/Panel\%20V\%20Sodhi.pdf, accessed November 20, 2019.

Stockholm International Peace Research Institute (2017). Arms Transfers Database. https://www.sipri.org/databases/armstransfers, accessed 10 December 2019. 
Sunkel, O. (1969). National Development and External Dependence in Latin America, Journal of Development Studies.

Taylor, I. (2007). China's relations with Nigeria. The Round Table: The Commonwealth Journal of International Affairs, Vol. 96, pp. 631-645.

Taylor, I. (2008). Sino-Nigerian Relations: FTZs, Textiles and Oil, in Arthur Waldron (ed.), China in Africa, Washington DC: Jamestown Foundation.

Taylor, I. (2015). Chinese interest in Nigeria's oil and the American context. Canadian Journal of African Studies/Revue Canadienne des études Africaines, Vol. 48, pp. 391404.

Theafricareport Online (2019). China's growing reach in Africa: are we seeing a fair trade? 19 September 2019. https://www.theafricareport.com/17380/chinas-growingreach-in-africa-are-we-seeing-a-fair-trade/, accessed on December 12, 2019.

Thinkers Newspaper (2019). Outcomes and Gains of President Buhari's Foreign Travels: 2015-2019, December 30. https://www.thinkersnewsng.com/outcomes-andgains-of-president-buharis-foreign-travels-2015-2019/, accessed January 15, 2020.

This Day (2016). Africa Today's Conference on Nigeria-China Relations and Implications for Nigeria's Foreign Policy Concentricism. May 8, www.thisdaylive.com/index.php/2016/05/08/

Africa-todays-conference-on-nigeria-china-relations-and-implications-for-nigeriasforeign-policy-concentricism/, accessed November 20, 2019.

Toogood, K. (2016). Understanding the Emerging Relationship between China and Africa: The Case of Nigeria. Policy Brief, School for Conflict Analysis and Resolution, George Mason University/Stimson Centre.

Udeala, S.O. (2010). Nigeria-China Economic Relations under the South-South Cooperation, African Journal of International Affairs, Vol.13 (1\&2), pp. 61-88.

UNCTAD (2018). Online Stats. http://unctad.org/en/Pages/Statistics.aspx, accessed December 12, 2019.

Utomi P. (2008). China and Nigeria. Washington, DC: Center for Strategic and International Studies.

Wong, L. (2009). The Impact of Asian National Oil Companies in Nigeria. London: Chatham House. 
Author's Biography: Goke Kuti is currently a $\mathrm{PhD}$ candidate in the Department of Political Science, Ekiti State University. His Doctoral research focuses on the Nigeria's external relations with the superpowers, especially the United States and China, since her returned to a democratic order in 1999. Kuti has deep research interest in international affairs, especially as it affects Africa. He combines his academic pursuit with pastoral work at the Redeem Christian Church of God (RCCG) as the current Regional Head of RCCG Region 25, Ekiti State.

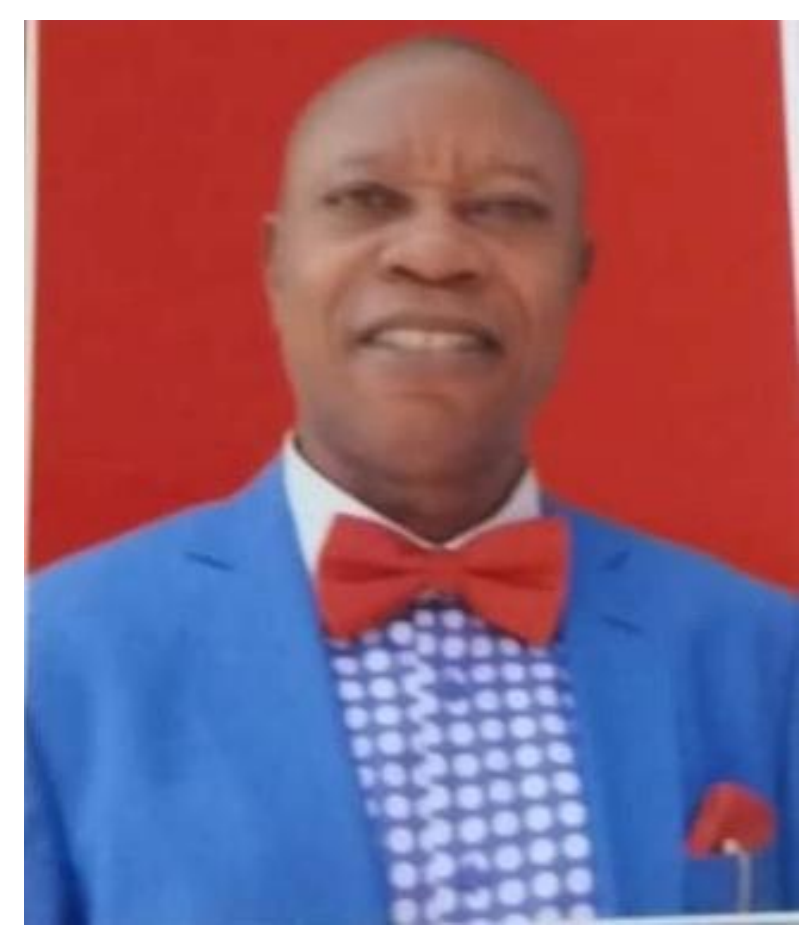

Author's Photo: Goke Kuti. 